\title{
An integrated lean approach to Process Failure Mode and Effect Analysis (PFMEA): A case study from automotive industry
}

\author{
Banduka, N. ${ }^{a}{ }^{a},{ }^{*}$, Veža, I. ${ }^{a}$, Bilić, B. ${ }^{a}$ \\ a University of Split, Faculty of Electrical Engineering, Mechanical Engineering and Naval Architecture, Split, Croatia \\ ${ }^{b}$ University of Kragujevac, Faculty of Engineering, Kragujevac, Serbia
}

\begin{abstract}
A B S T R A C T
Every automotive company is using ISO/TS 16949 standard for automotive industry. According to this standard of Process failure mode and effect analysis (PFMEA), is obligatory. Also, the application of lean in automotive industry is a trend nowadays. Both, PFMEA and lean have the same main purpose identification, prevention, and correction of failures during the production process. But, PFMEA have many shortcomings. In this paper, an integrated lean approach to PFMEA for solving specific shortcomings, is presented. This approach is new and it has not been used until now. Lean approach (tools and principles), were integrated in PFMEA. The new approach to solving PFMEA was presented in algorithm form. Some of those lean tools and principles integrated in PFMEA are: Genchi Genbutsu, Kaizen, standardized work, Jidoka, and 5 why. The approach presented was realized in a case study from automotive industry where traditional approach to PFMEA was compared to the new lean approach integrated to PFMEA. Changed and improved conditions were: number of team members, the actions taken, identification of failures, change of Severity (S), Occurrence (O), detection (D) and risk priority number (RPN) values, reduced S, O, D, and RPN values after taken actions, RPN with value over 100 , and S, 0 , D indexes with value over 8 .
\end{abstract}

\section{ARTICLE INFO}

Keywords:

Lean approach

Process failure mode and effect

analysis (PFMEA)

Automotive industry

*Corresponding author:

nikola.banduka90@gmail.com

(Banduka, N.)

Article history:

Received 8 July 2016

Revised 19 November 2016

Accepted 21 November 2016

\section{References}

[1] Harrison, A., van Hoek, R. (2005). Logistics management and strategy, Pearson Education, Harlow, England.

[2] Stamatis, D.H. (2003). Failure mode and effect analysis: FMEA from theory to execution, ASQ Quality Press, Milwaukee, Wisconsin, USA.

[3] ISO 9000. Quality management systems - Fundamentals and vocabulary, FMEA obligations, from http://www.bti.secna.ru/education/smq/docs/news/iso 9000 2005 e.pdf accessed October 30, 2016.

[4] ISO/TS 16949:2002(E). Quality management systems - Particular requirements for the application of ISO 9001: 2000 for automotive production and relevant service part organizations, FMEA obligations, from https://ciiaas.files.wordpress.com/2007/11/iso-ts-16949-2002.pdf, accessed June 13, 2016.

[5] Johnson, K.G., Khan, M.K. (2003). A study into the use of the process failure mode and effects analysis (PFMEA) in the automotive industry in the UK, Journal of Materials Processing Technology, Vol. 139, No. 1-3, 348-356, doi: 10.1016/S0924-0136(03)00542-9.

[6] Liu, H.C., Liu, L., Liu, N. (2013). Risk evaluation approaches in failure mode and effects analysis: A literature review, Expert systems with applications, Vol. 40, No. 2, 828-838, doi: 10.1016/j.eswa.2012.08.010.

[7] Biddle, J. The lean benchmark report, from http://consumergoods.edgl.com/column/The-Lean-BenchmarkReport48987 accessed June 13, 2016. 
[8] Lorenc, M., Jentzsch, A., Andersen, M., Noack, B., Waffenschmidt, L., Schuh, G., Rudolf, S. The lean advantage in engineering: developing better products faster and more efficiently, from $\underline{\text { htps://www.bcgperspectives.com }}$ accessed June 13, 2016.

[9] Chrysler LLC, Ford Motor Company, General Motors Corporation, Potential failure mode and effect analysis (FMEA), Reference Manual, $4^{\text {th }}$ edition, from www.engmatl.com/home/finish/20-engineering.../160-fmea-manual, accessed June 13, 2016.

[10] Korenko, M., Krocko, V., Kaplík, P. (2012). Use of FMEA method in manufacturing organization, Journal of Manufacturing and Industrial Engineering, Vol. 11 No. 2, 48-50.

[11] Montgomery, T.A., Pugh, D.R., Leedham, S.T., Twitchett, S.R. (1996). FMEA automation for the complete design process, In: Proceedings of Reliability and Maintainability Symposium - International Symposium on Product Quality and Integrity, IEEE, Las Vegas, NV, USA, 30-36.

[12] Vujica-Herzog, N., Tonchia, S. (2014). An instrument for measuring the degree of lean implementation in manufacturing, Strojniški vestnik - Journal of Mechanical Engineering, Vol. 60, No. 12, 797-803, doi: 10.5545/svjme.2014.1873.

[13] Liker, J.K. (2004). The Toyota way, 14 management principles from the world's freatest manufacturer, McGrawHill, New York, USA.

[14] Womack, J.P., Jones, D.T. (2010). Lean thinking: Banish waste and create wealth in your corporation, Simon and Schuster, New York, USA.

[15] Shekari, A., Fallahian, S. (2007). Improvement of lean methodology with FMEA, In: Proceedings of the 18 ${ }^{\text {th }}$ Annual Conference - POMS (Production and Operation Management Society), Texas, USA, 007-0520.

[16] Sawhney, R., Subburaman, K., Sonntag, C., Rao Venkateswara Rao, P., Capizzi, C. (2010). A modified FMEA approach to enhance reliability of lean systems, International Journal of Quality \& Reliability Management, Vol. 27, No. 7, 832-855, doi: 10.1108/02656711011062417.

[17] Shahrabi, M., Shojaei, A.A. (2014). Application of FMEA and AHP in lean maintenance, International journal of Modern Engineering Science, Vol. 3, No. 1, 61-73.

[18] Puvanasvaran, A.P., Jamibollah, N., Norazlin, N., Adibah, R. (2014). Poka-Yoke Integration into process FMEA, Australian Journal of Basic and Applied Sciences, Vol. 8, No. 7, 66-73.

[19] Puvanasvaran, A.P., Jamibollah, N., Norazlin, N. (2014). Integration of POKA YOKE into process failure mode and effect analysis: A case study, American Journal of Applied Sciences, Vol. 11 No. 8, 1332-1342, doi: 10.3844/ ajassp.2014.1332.1342.

[20] Teoh, P.C., Case, K. (2007). An evaluation of failure modes and effects analysis generation method for conceptual design, International Journal of Computer Integrated Manufacturing, Vol. 18, No. 4, 279-293, doi: 10.1080/ 0951192042000273122.

[21] Arabian-Hoseynabadi, H., Oraee, H., Tavner, P.J. (2010). Failure modes and effects analysis (FMEA) for wind turbines, International Journal of Electrical Power \& Energy Systems, Vol. 32 No. 7, 817-824, doi: 10.1016/j.ijepes. 2010.01.019.

[22] Moore, C. Failure Modes and Effects Analyses (FMEA) and critical items list (CIL) for the ECS project; EOSDIS core system project, from https://prod.nais.nasa.gov/eps/eps_data/161793-AMEND-002-002.pdf, accessed November 13, 2016.

[23] Liker, J., Convis, G.L. (2011). The Toyota way to lean leadership: Achieving and sustaining excellence through leadership development, McGraw Hill Professional, New York, USA. 


\section{APEM}

\title{
Integriran vitki pristop za analizo vpliva napak v procesu (PFMEA): Študija primera v avtomobilski industriji
}

\author{
Banduka, N. ${ }^{a}{ }^{a},{ }^{*}$, Veža, I. ${ }^{a}$, Bilić, B. ${ }^{a}$ \\ ${ }^{a}$ University of Split, Faculty of Electrical Engineering, Mechanical Engineering and Naval Architecture, Split, Croatia \\ buniversity of Kragujevac, Faculty of Engineering, Kragujevac, Serbia
}

\section{POVZETEK}

Vsako avtomobilsko podjetje uporablja standard ISO/TS 16949 za avtomobilsko industrijo. V skladu s tem standardom je analiza vpliva napak v procesu (angl. PFMEA) obvezna. Tudi vitkost je današnji trend v avtomobilski industriji. PFMEA in vitkost imata enak cilj - prepoznavanje, preprečevanje in popravljanje napak med proizvodnim procesom. PFMEA ima številne pomanjkljivosti. V tem prispevku je predstavljen vitki pristop za rešitev specifičnih pomanjkljivosti metode PFMEA. Pristop je nov in do sedaj ni bil uporabljen. Pristopi vitkosti (orodja in načela) so bili vključeni $v$ metodo PFMEA. Nov pristop reševanja analize vpliva napak $\mathrm{v}$ procesu je prikazan $\mathrm{v}$ algoritmični obliki. Nekatera orodja in načela vitkosti, vključena v PFMEA so: Genchi Gebustu, Kaizen, standardizirano delo, Jidoka in 5 why. Predstavljen pristop je bil uporabljen $\mathrm{v}$ študiji primera $\mathrm{v}$ avtomobilski industriji, kjer je bil tradicionalni pristop PFMEA primerjan $\mathrm{z}$ novim vitkim pristopom integriranim v PFMEA. Spremenjeni in izboljšani pogoji so: število članov ekipe, izvedene akcije, prepoznavanje napak, sprememba nujnosti $(\mathrm{N})$, pojavnost $(\mathrm{P})$, odkritje $(\mathrm{O})$, število rizične prednosti (ŠRP), zmanjšane vrednosti N, P, O in ŠRP po izvedenih akcijah, ŠRP vrednost preko 100 in N, P, O indeksi z vrednostjo preko 8.

\section{PODATKI O ČLANKU}

Ključne besede:

Vitki pristop

Analiza vpliva napak v procesu

(angl. PFMEA)

Avtomobilska industrija

*Kontaktna oseba: nikola.banduka90@gmail.com

(Banduka, N.)

Zgodovina članka:

Prejet 8. julija 2016

Popravljen 19. novembra 2016

Sprejet 21. novembra 2016 